\title{
Investigation of Academic Procrastination Prevalence and Its Relationship with Academic Self-Regulation and Achievement Motivation among High-School Students in Tehran City
}

\author{
Setareh Ebadi ${ }^{1} \&$ Reza Shakoorzadeh ${ }^{1}$ \\ ${ }^{1}$ Graduate Student of Educational Management at Allameh Tabataba'i University, Tehran, Iran \\ Correspondence: Setareh Ebadi, Graduate Student of Educational Management at Allameh Tabataba'i University, \\ Tehran, Iran. E-mail: setarehebadi1370@yahoo.com
}

Received: April 16, 2015 Accepted: May 19, 2015 Online Published: September 28, 2015

doi:10.5539/ies.v8n10p193 URL: http://dx.doi.org/10.5539/ies.v8n10p193

\begin{abstract}
The present study was carried out with the aim of Investigation of academic procrastination prevalence and its relationship with academic self-regulation and achievement motivation among high-school students in Tehran city. The sample included 624 high school students (312 Boys \& 312 Girls) from different areas and regions that selected using random cluster-multistage sampling method. Procrastination Assessment Scale-Student (Solomon \& Rothblum, 1984), Self-Regulated Learning Strategies questionnaire (Zimmerman \& Pons, 1982) and Achievement motivation test (Hermans, 1970) were used in this study. Data were analyzed in two parts, descriptive and inferential statistics. The results of academic procrastination prevalence using descriptive statistic showed that over half of students nearly always or always procrastinate. Also, results showed that boys and girls procrastinate with the same rate, in general. And boys more than girls procrastinate only on preparing academic tasks. The result of regression analysis also showed that academic self-regulation and achievement motivation predict academic procrastination significantly.
\end{abstract}

Keywords: academic procrastination, self-regulation learning, achievement motivation

\section{Introduction}

Success and achievement is one of the major concerns of students, parents and the educational system in generally. Academic success of every community, demonstrates efficient and successful of student's and education system. On the other hand, from point view of parent's, most important indicator for education is that their children will be able well done assigned tasks in the future. In this regard, the British biologist and educator of the nineteenth century, Thomas Huxley noted "Perhaps the most valuable result of all education is the ability to force yourself to do something, when it should be done, whether you like it or not. In fact, this is the first lesson that should be learned" (Faran, 2004). One of the features that prevent from doing things well, to achieve success and progress, it is negligence .The term "negligence", taken from the Latin word Procrastinus, which pro means tomorrow is the front or leading and crastinus means tomorrow (Asif, 2011) And then combine it means to postpone, delay, extend, postpone, postpone or fail to perform a task (Rosario et al., 2009; Abedi et al., 2012a). Based on Steele (2007) negligence is the intentional and deliberate behavior of activity that delayed despite the expected deterioration of the situation. The New Dictionary of Twentieth Century (1983, quoted by Faran, 2004) defines negligence as "delaying current act until the uncertain future". This means that according to this definition, a person is negligent, habit of postponing the acts. Johnson and Mccown (1995) define negligence as repeated delays in starting or completing tasks that approaching deadline .Many researchers believe that each of us at some time in their lives have suffered neglect and this complex phenomenon, beings widespread and rampant problem among human. Generally, it has been reported that $\% 20$ of the negligence among adults population, it is common; However, the neglect in the population of education graduates reaches $65 \%$ (Hariot \& Ferrari, 1996). Hence, given the increasing prevalence of this behavior, identify negligence in the field of education occurs with other types of negligence, to seem be efficient and beneficial (Ferrari et al., 1995; quoted Strand 13, 2009).

Neglect of education, type of negligence which may ultimately be reflected in academic areas and structures. And is the tendency to deliberately delay or failure to complete academic tasks that are associated with adverse 
experiences. In this regard, Ellis and Nas (2002) has stated academic negligence a desire to avoid doing an activity or late to do it and appeal to various excuses to justify the delay behavior to avoid others blaming (Aremu, Williams, \& Adesina, 2011) That appear the delay in activities such as, studying and preparing for exams, writing papers and final weekly reading assignments (Solomon \& Ruthblum, 1984).

To witness a lot of research neglect, especially among the students is a common phenomenon and the process is now in the age of technology is increasing (Asif, 2011). For example, in the context of negligence as that $70 \%$ of students is negligence and delay behavior (Ellis \& Nas, 1997; quoted Deniz, Tras, \& Aydogan, 2009). That 50\% of them, at least in their half time negligence at academic responsibilities and duties, and only $38 \%$ of them have rarely been lax (Solomon \& Ruthblum, 1984). The more research that has been done in this area, the incidence of negligence in Klasn et al. (2008) studies 89\%, Ferrari, Demir, and Ozer (2009) studies 52\%, And in the review Asif (2011) is based on previous research, \%90-75 have been reported. Also Kagan (2009) in their study concluded that half of the students are negligent. Conducted researches about effects of gender on academic negligence are largely vague and ambiguous. Some studies indicate that there aren't gender differences in the degree of negligence (Solomon \& Ruthbloom, 1984; Lu, 2010). Some believe that men than women, have become more negligence (Ozer, Demir, \& Ferrari, 2009). Generally, negligence with a high incidence appears and to be lead of wide and debilitating consequences (Rice, Neimeyer, \& Taylor, 2011; Abedi et al., 2012b).

Research suggests, negligence associated with abnormal pattern of life, this can lead to serious problems of personal and social influences (Bvrka \& Yan, 1983; Rsaryv et al., 2009). In the present study among students, a common assumption is that negligence is the enemy of learning. Which often leads to failure and improper assignments to complete. It is important that the negligence of one of the serious obstacles to learners progress and achievement (Sokoloska, 2011).

In summary, the experts are agreeing about the adverse consequences of negligence behavior. Where negligence as an adjective considered that has the components of cognitive, behavioral and motivational (Buffeli, 2007). It seems there are thousands due to careless behavior (Strand, 2011). Preliminary investigation on the grounds of negligence reasons in clinical practice Bvrka and Yan (1983, quoted by Ozer, Demir, \& Ferrari, 2009) revealed that people because of anxiety of assessment, difficulty in making decisions, disobeying the control of others, lack of courage, fear of successful outcomes, assignments galling, having high standards for their perfectionism, conducted negligence. Other scholars (such as Solomon and Ruth Bloom, 1984; Ferrari and Taisei, 2000), fear of failure, lack of energy, the thorny task, impulsivity and low self-irregularities, are known the causes of negligence. In recent years, negligence has been proposed as a "defect in self-regulation" (Steele, 2007). Generally, self-regulation is use of internal and external cues to initiate, maintain and end the targeted activities (Buffleli, 2007; Lee, 2005). Self-regulation of learning the concept that deals the individual's role in the learning process. In learning the importance of these structures to the extent that, various scholars have proposed different models of it. Among these models, is Pintrich and DeGroot (1990) pattern. According to this model, the self-regulation of learning refers to optimize the use of cognitive and metacognitive and resource management to maximizes learning (Pyntrych \& DeGroot, 1990). A cognitive strategy, refers to any behavior or act or thought that its aim to help acquire, organize and store knowledge and make ease to operation in the future. These include strategies of repetition and review, develop and organize (Saif, 2010). Metacognitive strategies are monitoring and they are used on surveillance and guidance of cognitive strategies, Strategies for resource management are strategies facilitators and learners are often used to control and managing the environment, including management of time regulation, the effort, the selection of the study and get help from other people such as teachers, peers, resources and etc. (Zimmerman \& Pons, 1986).

Research findings in this area suggest that negligence in connection with the styles of self-regulation in the field of education (Lee, 2005). With this in mind that it is important self-regulation skills knowledge, confidence in the use and application of these skills is an important factor in the initiation and completion of tasks (Klasn et al., 2008). Therefore (Tan et al., 2008, quoted by Le, 2010), in the study on Singaporean students found that students who perceive themselves ability in regulate and organize their learning, likely than other students are less negligence.

Other contingency for academic negligence is lack of progress motivation (Steele, 2007; Kagan, 2008). According to psychologists, achievement motivation is and desire or effort that the person expression to achieve a goal or mastery of objects, things, people, ideas and achieve a higher standard of its own (Parsa, 1995) and a tendency to try to choose activities that aims to achieve success or avoid failure (Kadivare, 2007). According to the results of the research in this area, motivation learning is a significant factor in predicting student education achievement quality, welcomed the encounter or avoid situations and learning challenging assignments and the carelessness and negligence of their (Elliot \& Duke, 1988). In this regard, given the incentive structures, it has 
been found that the negligence involved a motivational problem, as negligence's hardly are raised; Therefore more likely to work in the school and study for exams until the last possible moment, they negligence (Takmn, 1998, quoted by Lee, 2005). Negligence often know exactly what is needed to complete a given task but mostly in excited their motivation to achieve academic goals on given time and fail (Strand, 2011).

Finally, with regard to those who passed, it must be noted that little research has been done whether on the Evaluation of prevalence of education negligence especially in Iran and whether evaluation of the relationship between academic negligence and self-regulation and achievement motivation, so further research in this area will require. Therefore the present study is an attempt to collect and provide additional information in this field.

The present study was carried out with the aim of Investigation of academic procrastination prevalence and its relationship with academic self-regulation and achievement motivation among high-school students. In this context, the following questions were raised:

1) How much is the prevalence of neglect of education among students?

2) Is the prevalence of negligence among girls and boys different?

3) Does self-regulation of learning and achievement motivation, are predictors of negligence?

\section{Methods}

The present study was carried out with the aim of Investigation of academic procrastination prevalence and its relationship with academic self-regulation and achievement motivation. So, this is the study of epidemiology. The population was considered of all students, boys and girls high school in Tehran. Also, sampling was multistage cluster sampling. For sampling, Tehran was divided to North, South, Central, East and West and among each of the counties a region and among each of the area a school for girls and boys were randomly selected. The sample consisted of 624 high school students from different grades that among these 312 person girl and 312 people were boys. In this study, the assessment of negligence-student's version, self-regulated learning strategies questionnaire and motivation achievement test was used;

\section{Results}

In this section, the data collected were analyzed in two parts, in the first section, using descriptive statistics such as frequency, percentage, statistics such as mean, standard deviation and standard error of the mean, the collected data is described and In part two, based on using the inferential statistics, research questions were analyzed .

1) Data analysis with descriptive statistics

\section{1-1) Gender}

Table 1. Descriptive data on the gender of participants

\begin{tabular}{llll}
\hline & Percent & Frequency & Congestion percent \\
\hline Girl & 50 & 312 & 50 \\
Boy & 50 & 312 & 100 \\
The total & 100 & 624 & \\
\hline
\end{tabular}

As shown in Table 1 in terms of gender, $\% 50(n=312)$ of the sample were female and $\% 50(n=312)$ were male.

2-1) descriptive statistics for the variables 
Table 2. Standard scores of subjects in the variables according to sex

\begin{tabular}{|c|c|c|c|c|c|c|c|c|c|}
\hline \multirow{3}{*}{ Variable name } & \multicolumn{6}{|c|}{ Gender } & \multirow{2}{*}{\multicolumn{3}{|c|}{ Total }} \\
\hline & \multicolumn{3}{|c|}{ boy } & \multicolumn{3}{|c|}{ girl } & & & \\
\hline & $\mathrm{M}$ & SD & SEM & M & SD & SEM & $\mathrm{M}$ & SD & SEM \\
\hline Achievement Motivation & 83.43 & 10.86 & 0.615 & 83.16 & 8.96 & 0.507 & 83.30 & 9.95 & 0.39 \\
\hline Self-regulation of learning & 82.61 & 43.52 & 2.64 & 81.64 & 44.8 & 2.49 & 81.9 & 43.76 & 1.75 \\
\hline $\begin{array}{l}\text { Negligence (most of the time } \\
\text { or always) }\end{array}$ & 44.34 & 10.07 & 0.57 & 43.19 & 9.92 & 0.56 & 43.77 & 10.0 & 0.40 \\
\hline Prepare for Exams & 13.42 & 4.38 & 0.24 & 13.44 & 3.54 & 0.20 & 13.43 & 3.98 & 0.15 \\
\hline Preparing assignments & 18.05 & 5.06 & 0.28 & 16.98 & 4.74 & 0.26 & 17.52 & 4.93 & 0.19 \\
\hline Preparation of final papers & 12.94 & 3.86 & 0.21 & 13.30 & 5.08 & 0.28 & 13.12 & 4.51 & 0.180 \\
\hline
\end{tabular}

2) Data analyze, using inference statistical

Analysis results of data related to research questions are as follows

Question 1: How much is the prevalence of academic negligence?

According to the collected data, the prevalence of negligence (Often or Always) among subjects is 51.12 percent; and the prevalence of small-scale: preparing for exams, preparing assignments and preparing final papers respectively is equal to $46.66,47.27$, and 47.59 . The incidence of negligence and subscales: preparing for exams, preparing assignments and preparing final papers in the sample, the gender breakdown respectively, is as follows: In the Boys 49.03, 48.71, 43.26, 44.55, and girls, 96.50 46.15, 50, 48.39.

Question 2: Is the prevalence of negligence among girls and boys different?

Table 3. Comparison of male and female students in variable negligence and its subscales

\begin{tabular}{|c|c|c|c|c|c|c|}
\hline Variables & Groups & Mean & SD & $\mathrm{t}$ & df & Significance level \\
\hline \multirow{2}{*}{ Negligence (most of the time or always) } & Boy & 44.34 & 10.07 & \multirow{2}{*}{1.437} & \multirow{2}{*}{622} & \multirow{2}{*}{0.151} \\
\hline & Girl & 43.19 & 9.92 & & & \\
\hline \multirow{2}{*}{ Prepare for Exams } & Boy & 13.42 & 4.38 & \multirow{2}{*}{$0.050-$} & \multirow{2}{*}{622} & \multirow{2}{*}{0.960} \\
\hline & Girl & 13.44 & 3.54 & & & \\
\hline \multirow{2}{*}{ Preparing assignments } & Boy & 18.05 & 5.06 & \multirow{2}{*}{2.732} & \multirow{2}{*}{622} & \multirow{2}{*}{0.006} \\
\hline & Girl & 16.98 & 4.74 & & & \\
\hline \multirow{2}{*}{ Preparation of final papers } & Boy & 12.94 & 3.86 & \multirow{2}{*}{$0.993-$} & \multirow{2}{*}{622} & \multirow{2}{*}{0.321} \\
\hline & Girl & 13.30 & 5.08 & & & \\
\hline
\end{tabular}

According to the results listed in Table 3, we conclude male and female students only in preparing homework subscales are significantly different. Because the calculated $t$-value for this scale $(t=2.732)$ from Table $t$-value (2.732) in degrees of freedom 622 is greater than the null hypothesis is rejected.

Thus, we can conclude with \% 99 confidences, contrary assumption based on the difference between male and female students in the preparation of the assignments scale confirmed. However, the calculated t-value for the scale of neglect, prepare for exams and preparing final papers which respectively are 1.437, - 0.050, - 0.993 from Table t-value (2.732) in degrees of freedom 622 is smaller, and the null hypothesis is confirmed. Thus, we can conclude with $\% 99$ confidences, contrary assumption based on the difference between male and female students in the scales: negligence, prepare for exams and preparing final papers rejected.

Question 3: Is self-regulation of learning and achievement motivation predicted education negligence?

Now, by using multivariate regression, we examined the effect of negligence predictors Variables. 
Table 4. The descriptive statistics of regression model

\begin{tabular}{ccccc}
\hline Standard error of estimate & R Square Set & R Square & R & Model \\
\hline 8.64 & 0.253 & 0.256 & $0.505^{\mathrm{a}}$ & \\
\hline
\end{tabular}

'a' predicates: Self-regulation of learning and achievement motivation.

As data of table 4 shows Predictor variables only predicted 0.253 percent of the criterion variable. That this amount represents the addition of variables and other factors that affect the occurrence of negligence but is not covered in this study.

Table 5. Regression analysis

\begin{tabular}{lccccc}
\hline Significance level & F & Squares mean & df & Sum of squares & Model \\
\hline $0.001^{\text {a }}$ & 106.564 & 7972.043 & 2 & 15944.086 & Regression \\
& & 74.810 & 621 & 46457.053 & The remaining \\
& & & 623 & 62401.139 & Total \\
\hline
\end{tabular}

'a' predicates: Strategies for the self-regulation and motivation development.

To determine the goodness of fit of the regression multivariate analysis of variance (ANOVA) was used according to the findings of the above table. As can be seen $\mathrm{F}$ test confirms in the 0.01 , that represents the model at the level of 0.01 is significant.

Table 6. Standardized regression coefficients

\begin{tabular}{lc}
\hline Variables & Beta coefficient \\
\hline Achievement Motivation & -0.484 \\
Self-regulation of learning & -0.092 \\
\hline
\end{tabular}

Table 7. Regression coefficients

\begin{tabular}{cccccc}
\hline \multirow{2}{*}{$\begin{array}{c}\text { Significance } \\
\text { level }\end{array}$} & $\mathrm{T}$ & $\begin{array}{c}\text { Standardized } \\
\text { coefficients } \\
\text { Beta }\end{array}$ & \multicolumn{2}{c}{$\begin{array}{c}\text { Not standardized } \\
\text { coefficients }\end{array}$} & Model \\
\cline { 4 - 5 } & & & B & Standard error & \\
\hline 0.001 & 29.269 & -0.484 & -0.478 & 0.035 & Achievement Motivation \\
0.001 & -13.834 & -0.092 & -0.021 & 0.008 & $\begin{array}{c}\text { Self-regulation of } \\
\text { learning }\end{array}$ \\
\hline 0.009 & -26.17 & & & & \\
\hline
\end{tabular}

As shown in the table above, it appears that factors related to achievement motivation and motivational beliefs at the level of 0.01 and the coefficient of self-regulatory strategies at the level of 0.05 is significant. And determine which variables achievement motivation and self-regulation of learning is negative predictors of educational neglect.

\section{Discussion and Conclusions}

As in the past, academic negligence is delays, deliberate and repeated behavioral that have emerged in the field of education and it's to become common among the graduates. Results of this study with aim to examine the prevalence of academic negligence among students, implying that more than half of the students in relation to academic tasks in frequently, often, or always, are negligence. These results are largely consistent with the findings of many researchers (eg, Solomon \& Ruthbloom, 1984; Kagan, 2009; Ferrari, Johnson, \& McDonald, 2005; Klasn et al., 2008; Hariot \& Ferrari, 1996) based on negligence is the high rate of school. 
On gender, the academic negligence researches, has largely equivocal, different, ambiguous and complex. Some of these studies (e.g., Ferrari et al., 1995; Kagan, 2009; Ozer \& Dmyrvfrary, 2009) suggest that males are more lax .However, other studies indicate that there is not significant relationship between gender and negligence (Clark \& Hill, 1994; Haykvk, 1993; Solomon \& Ruthblum, 1984). The results also indicate that there wasn't a significant relationship between gender and educational neglect.

Results of regression analysis showed that self-regulation of learning negatively predict negligence. This means that students who are weak in self-regulated at comparison to the students how have more self-regulation skills are far more likely to be lax. The result of the study is in line with many of the findings in this area (eg, Solomon \& Ruthblum, 1984; Takmn \& Sexton, 1989; quoted by Lee, 2005; Strand, 2009). It also may be due to social cognitive theory Zimmerman and Pons (1990) explained.

And finally, as well as the results of regression analysis showed that achievement motivation as self-regulation of learning negatively predicts academic negligence. This result is consistent with the findings of some researchers (eg, Steele, 2007; Lee, 2005).

Also explain this finding we can cite the characteristics of people with high achievement motivation. Those with high achievement motivation, they are perfect and want to improve their performance. They are conscientious and prefer to take things that is possible to assess progress as desired. They have self-esteem, prefer personal responsibility and like to be informed of any tangible of their work results (Biyabangarg, 2006; quoted desire Tamanayifar \& Gandomi, 2011). Which seems to contradict all these features is lax behavior.

In general, with regard to matters that is passed due to the limitations of the present study sample is limited to a certain degree Caution in generalizing the results to other populations should be followed, it is hoped that future research in this area could be resolved this limit. Also, the incidence of negligence in the crowd of graduates, necessary attention of education authorities, planners and practitioners manifested and review, appropriate actions to eliminate, reduce or prevent the abnormal behavior is essential.

\section{References}

Abedi, G., Rostami, F., \& Nikpor, B. (2012a). Analyzing of regression model of environmental health quality of residential in slum areas. International Journal of Collaborative Research on Internal Medicine \& Public Health, 4(2), 137-143.

Abedi, G., Rostami, F., Mohammadpor, R. A., Nejatizadeh, A., Eghbal-Eftekhaari, T., Miri, H. R., ... Alizadeh, A. (2012b). Phenomenology of Scientific Board's Views about Electronic Learning. Life Sci. J., 9(4), 535-539.

Aremu, A. O., Williams, T. M., \& Adesina, F. T. (2011). Influence of Academic procrastination and personality types on academic achievement and efficacy of in school adolescents in Ibadan. Ife psychology IA, 19(1), 93-113. http://dx.doi.org/10.4314/ifep.v19i1.64591

Asif, M. A. (2011). Clinical implication of Academic procrastination. A doctoral project submitted to the faculty of the California School of Professional Psychology in partial fulfillment of the requirements for her degree of Doctor of Psychology at Alliant International University, Los Angeles.

Clark, J. L., \& Hill. O. W. (1994). Academic procrastination among African-American college students. Psychological Reports, 75, 931-936. http://dx.doi.org/10.2466/pr0.1994.75.2.931

Deniz, M. E., Tras, Z., \& Aydogan, D. (2009). An investigation of academic procrastination, locus of control and emotional intelligence. Educational scinces: Theory and practice, 9(2), 623-632.

Elliot, E. S., \& Dweck, C. S. (1988). Goals: An approach to motivation and achievement. Journal of personality and social psychology, 54, 5-12. http://dx.doi.org/10.1037/0022-3514.54.1.5

Ferrari, J. R., \& Harriott, J. (1996). Prevalence of procrastination among sample of adults. Psychological Reports, 78, 611. http://dx.doi.org/10.2466/pr0.1996.78.2.611

Ferrari, J. R., Johnson, J. L., McCown, W. G., \& Associates. (1995). Procrastination and Task avoidance: Theory, research and treatment. Canadian Journal Administrative, 13(2), 182-183. http://dx.doi.org/10.1007/978-1-4899-0227-6

Kadivar, P. (2007). Educational Psychology. Boomehen: Press the side.

Kagan, M. (2009). Determining the Variables Which Explain the Behavior of Academic Procrastination in University Students. Ankara University, Journal of Faculty of Educational Sciences, 42(2), 113-128.

Klassen, R. M., Ang, R. P., Chong, W. H., \& Krawchuk, L. (2010). Academic Procrastination in Two Settings: 
Motivation Correlates, Behavioral Patterns, and Negative Impact of Procrastination in Canada and Singapore. Applied psychology: An international Review, 59(3), 361-379. http://dx.doi.org/10.1111/j.1464-0597.2009.00394.x

Lee, E. (2005). Relationship of Motivation and Flow Experience to Academic Procrastination in University Student. The Journal of Genetic Psychology, 166(1), 5-14. http://dx.doi.org/10.3200/GNTP.166.1.5-15

Ozer, B. U., Demir, A., \& Ferrari, J. R. (2009). Exploring Academic Procrastination among Turkish Students: Possible Gender Differences in Prevalence and Reasons. The Journal of social psychology, 49(2), 241-257. http://dx.doi.org/10.3200/SOCP.149.2.241-257

Parsa, M. (1995). Educational Psychology. Tehran: Parsa

Pintrich, P. R., \& DeGroot, E. V. (1990). Motivational and self-regulated learning components of classroom Academic performance. Journal of educational psychology, 82(1), 33-40. http://dx.doi.org/10.1037/0022-0663.82.1.33

Rice, G. K., Neimeyer, G. J., \& Taylor, J. M. (2011). Efficacy of Coherence Therapy in the Treatment of Procrastination and Perfectionism. Counseling Outcome Research and Evaluation, 2(2), 126-136. http://dx.doi.org/10.1177/2150137811417975

Rosario, P., Costa, M., Nunes, J. C., \& Pienda, J. G. (2009). Academic procrastination: Association with personal, school and family variables. The Spanish journal of psychology, 12(1), 118-129. http://dx.doi.org/10.1017/S1138741600001530

Saif, A. A. (2010). Learning and study. Tehran: Nshrdvran.

Solomon, L. J., \& Rothblum, E. D. (1984). Academic procrastination: Frequency and Cognitive-Behavioral correlates. Journal of counseling psychology, 31(4), 503-509. http://dx.doi.org/10.1037/0022-0167.31.4.503

Steel, P. (2007). The Nature of Procrastination: A Meta-Analytic and Theoretical Review of Quintessential $\begin{array}{lllll}\text { Self-Regulatory Failure. } & \text { Psychological }\end{array}$ http://dx.doi.org/10.1037/0033-2909.133.1.65

Steel, P., Brothen, T., \& Wambach, C. (2001). Procrastination and personality, performance and mood. Psychology and individual differences, 30, 95-106. http://dx.doi.org/10.1016/S0191-8869(00)00013-1

Strand, K. H. (2009). The behavioral effects of consideration of future consequences and time perspective on Self-Regulation and Procrastination in mastery college students. A dissertation submitted in partial fulfillment of the requirements for the degree of Doctor of Philosophy in the College of Education at the University of Kentucky.

Tamanayifar, M., \& Gandomi, Z. (2011). Relationship between achievement motivation and academic achievement of students. Journal of Educational Strategies, 4(1), 15-19.

Tice, D. M., \& Baumeister, R. F. (1997). Longitudinal Study of Procrastination, Performance, Stress, and Health: The Costs and Benefits of Dawdling. American Psychological Society, 8(6), 454-458. http://dx.doi.org/10.1111/j.1467-9280.1997.tb00460.x

Zimmerman, B. J., \& Pons, M. M. (1986). Development of a Structured Interview for Assessing Student Use of Self-Regulated Learning Strategies. American Educational Research Journal, 23(4), 614-628. http://dx.doi.org/10.3102/00028312023004614

\section{Copyrights}

Copyright for this article is retained by the author(s), with first publication rights granted to the journal.

This is an open-access article distributed under the terms and conditions of the Creative Commons Attribution license (http://creativecommons.org/licenses/by/3.0/). 